\title{
Mangled Extremity Severity Score - is it really useful in assessing limb salvage following open and crush injuries in the lower extremity?
}

Thomas Kurien Bhanu

From International Summit on Emergency Medicine and Trauma 2014

Puducherry, India. 12-16 February 2014

\section{Objective}

To assess the utility of Mangled Extremity Severity Score in the injured lower limb.

\section{Methods}

This study was done in the Accident \& Emergency Centre of a tertiary hospital in India.

This is a descriptive study assessing the validity of the MESS score in predicting limb salvage.

The study included patients older than 18 years with open injuries/crush injuries of the lower extremities up to the level of the ankle (Gustilo and Anderson type III B / III C injuries).

Patients were divided into those who presented within 6 hours and those after 6 hours of injury. The final study consisted of 50 patients with 51 lower limb injuries. The study was conducted over a span of 18 months.

\section{Results}

- The MESS mean score in the salvaged group were 4.36 and in the amputated group were 8.42 .

- Thus the sensitivity was $75 \%$, specificity $92.31 \%$, positive predictive value $75 \%$ and negative predictive value $92.31 \%$.

- After calculation of the receiver operator characteristic (ROC) curves and calculation of area under the curves (AUC) as 0.935 , a score of 7 or greater predicted amputation with the highest sensitivity and specificity.

\section{Limitations}

As this is a prospective study in a limited time frame, the long term follow up is not known. It is also not

Correspondence: thomaskbhanu@gmail.com

Christian Medical College, Vellore, India known from our study nor from other previous studies whether the MESS distinguishes between functional and nonfunctional salvage.

\section{Conclusion}

A total score of $\geq 7$ is significantly associated with amputation both in the primary amputation group as well as in the combined primary and delayed amputation group.

Thus the utility of MESS as a tool in assessing limb salvage following open and crush injuries to the lower extremity has been validated.

Published: 25 July 2014

\section{doi:10.1186/1865-1380-7-S1-P6}

Cite this article as: Bhanu: Mangled Extremity Severity Score - is it really useful in assessing limb salvage following open and crush injuries in the lower extremity? International Journal of Emergency Medicine 2014 7(Suppl 1):P6.

Submit your manuscript to a SpringerOpen ${ }^{\odot}$ journal and benefit from:

- Convenient online submission

- Rigorous peer review

- Immediate publication on acceptance

- Open access: articles freely available online

- High visibility within the field

Retaining the copyright to your article

Submit your next manuscript at $>$ springeropen.com

(c) 2014 Bhanu; licensee Springer This is an Open Access article distributed under the terms of the Creative Commons Attribution License (http://creativecommons.org/licenses/by/2.0), which permits unrestricted use, distribution, and reproduction in any medium, provided the original work is properly credited. 